\title{
On the amount and timing of project payments with hints to customary contracting in Germany
}

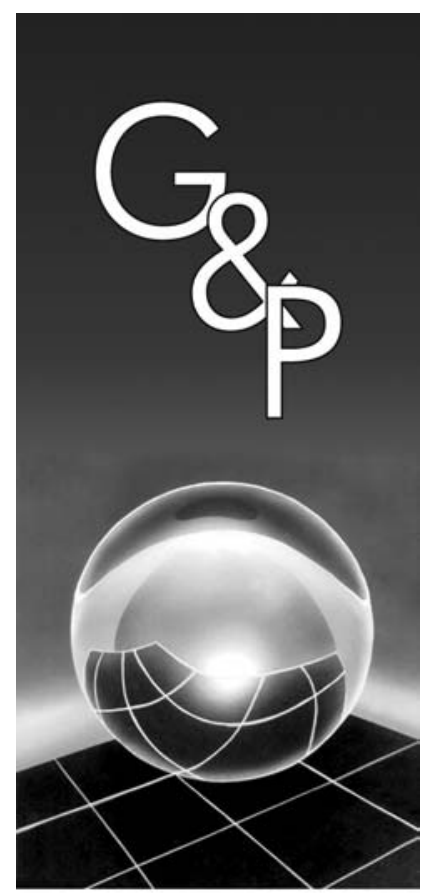

Alf Kimms

Abstract

A huge number of publications deal with project scheduling and very often the objective is to minimize the makespan. We claim that in the real world money counts. Therefore, we review how project payments can be defined in practice. The issues of contracting and bidding are discussed to demonstrate that a whole universe of specific model formulations would be needed to cover real situations.

Keywords: Project management. Contracting. Bidding.

INVITED PAPER

\section{Introduction}

Managing a project covers a bundle of actions to be taken in order to achieve good performance. Some of the decisions to be made are listed below, and similar outlines can be found in some other project management textbooks as well (KIMMS, 2001; SHTUB et al., 1994).

a) project selection: often, a firm can select one project at a time, but not every one of them should be accepted. Even if several projects look advantageous, the firm may not be in the position to accept all of them because of scarce resources. So, feasibility studies must be made. A portfolio of projects must eventually be selected;

b) organizing: general guidelines on how to measure the performance of a project, for example, are to be defined. A team responsible for the project must be set up i.e., the size of the team must be defined and team members must be assigned to the project. In addition, the project participants must be organized e.g. in a matrix organization or in a project-oriented organization;

c) contracting: a contract should be prepared to protect the contractor as well as the client. Besides other things, the contract should define how the price of the project is calculated and when payments are in order;

d) bidding: sometimes a contract is awarded by means of a bidding procedure. The client then receives bids from several potential contractors. A serious problem for a bidder is to define a competitive bid price;

e) financing: capital resources must be obtained to finance a project. At a corporate level, multiple projects must be financed together;

f) project planning: the objective of this phase is to figure out the structural details of a project. Project planning should answer questions such as: What tasks are to be performed to fulfill the project? What precedence constraints among the tasks are to be respected due to technological reasons? How long will each task last? What resources are required to perform the tasks? What number of resources is required to perform certain tasks? and What cash flow is associated with each task?;

g) due date setting: usually, a desired date of completion is negotiated. Especially from the contractor's perspective it is important that this date is met 
respecting all side- constraints because not meeting the due date may cause penalty payments or loss of the client's goodwill;

h) scheduling: before starting to realize a project, one should have planned when to start and when to finish the tasks in a way that all side constraints are taken into account; and

i) monitoring and controlling: once a project is started, it must be supervised until its completion. The cost, the timing, and the quality are to be monitored and reported, and efforts should be undertaken to guarantee the success of the project. It is sometimes necessary to abort a project in order to prevent serious economic damages.

The above list of items sketches some important project management issues. The focus of this paper is on contracting and bidding. Customary implementations are reviewed and the reader is introduced to the legal system in Germany concerning contracting.

\section{Contracting}

If the two independent parties, client and contractor, agree to perform a project, they usually negotiate and sign a contract. If both parties come from the same country, its laws must be respected. Should the two parties come from different countries, it is advised to agree upon and state which nation's law — it can be a third nation should be upheld since only the laws that both countries have in common are applicable. This is, therefore, crucial to know whether and how law affects what is stated in the contract. In what follows, it will be described the frame provided by the German law and confine the discussion on issues that affect directly the amount and timing of payments, the major focus of this work.

Afterwards, we will give an overview of how the price for a project may be defined and calculated and how payments may be triggered. These two aspects do not only have an immediate impact on the financial performance, but when carefully designed they also may give incentives for desired behaviors such as completing the project fast. They may also help allocate risks which stems from wrong cost estimates and/ or from not fulfilling the contract properly. In addition to that, the definition of prices and more or less complex payment modes also affect the effort and thus the cost for monitoring and controlling the project. See Clough (1975), Gilbreath (1983), Hendrickson and Au (1989), Horgan and Roulston (1989), Marsh (1995), Neo (1976) and Twort and Rees (1995), for more details on contracting.

\subsection{German law}

The part of the German civil law (Bürgerliches Gesetzbuch - BGB) that is relevant for contracting projects includes some general laws ( $\$ 241-432$ BGB) and some laws that are specific to the type of contract applicable for projects ( $\$ 631-650 \mathrm{BGB})$. It can be said that the German legislator was focusing on skilled trade i.e., usually, the contractor hands the completed project over to the client within a fairly short time; the project price can then be defined in advance easily and payments are made after the inspection. However, the aforementioned laws may be augmented with individual agreements, which must be stated in the contract, so that other situations may be handled similarly although extra care is recommended.

\subsubsection{Legal framework}

Once a contract is signed, the contractor has the right to get paid by the client right away. This, however, does not mean that the contractor can claim getting paid right after signing the contract. Instead, such claims are in order only if the client has already inspected the completed project ( $\$ 641$ and $\$ 646 \mathrm{BGB}$ ). The client is obliged to inspect the completed project to ensure there are no flaws ( $\$ 640$ BGB). It is common sense that this is also true if one detects minor defects only. But in that case, the client can keep some money back until the contractor has repaired the defects. It is important to highlight that this money is different from the retention money which can be agreed upon in the contract. Retention money can be kept back during the guarantee period just in case there are faults during that period. The guarantee period ensured by law is of six months in general and the guarantee period is of five years for construction ( $\$ 638 \mathrm{BGB})$. If the contractor is not willing to repair a defect, or not able to do so, the client may repair the defect by himself/herself or may let someone else do it. In this case, the contractor must refund the repair cost ( $\$ 633$ III BGB), and the client can claim to have an advance.

It is noteworthy to mention that a check is not important, because the contractor's claim for being paid comes with the inspection. The date of inspection is important for other reasons as well. From that date on, the client must pay an interest for the payments the contractor has a claim on ( $\$ 641 \mathrm{BGB})$.

Rather than inspecting the project as a whole, the parties may state in the contract that some parts of the project should be inspected with a hire-purchase agreement ( $\$ 641$ BGB). It should be noted that legally a hire-purchase is different from an advance. Therefore, by law, usually the contractor is paid after his work is completed. For protection, the contractor is entitled with a right of distraint ( $\$ 647 \mathrm{BGB})$ and, in the case of a construction project, the right to mortgage ( $\$ 648 \mathrm{BGB}$ ). 
In general, law assumes that projects are not for free and a price must be paid if this is usually the case for similar projects ( $\$ 632 \mathrm{BGB})$. A case is assumed to be "usual", if at least one of the parties is a trader. If no price is defined in the contract, but the contractor can prove that paying a price is customary under similar circumstances, then the law says how to calculate a price: First, if a refunding is officially defined (as it is for architects, for instance), it is then valid. Second, if a refunding is not officially defined, the chamber of commerce, the trade corporation, or whoever is in command, defines a price. Otherwise, the contractor can define the price ( $\$ 315-316$ BGB).

\subsubsection{Contractual agreements}

It is clear that many details must be specified in a contract, and an efficient way to do that is to define some general terms of business that will become part of the contract. If one party wants to define general terms of business, it has to take into account a specific law (Allgemeine Geschäftsbedingungen Gesetz - AGBG) which defines how such general terms of business may become part of the contract ( $\$ 2 \mathrm{AGBG}$ ) and its contents as well ( $\S 9-11$ AGBG).

For construction projects, some general terms of business have been formulated, which usually become part of a contract (Verdingungsordnung für Bauleistungen VOB). In Germany $90 \%$ of the cases which come to court and which are related to project contracting are construction project cases (LOCHER, 1990).

It is sometimes necessary to agree upon payments that should be made during the project's run-time, before inspection. This is especially true when projects last long or when they require high investments. The parties are free to do so and may negotiate claims for payments. As mentioned above, one has to distinguish an advance and a hire-purchase.

As a means of pressure for fulfilling the contract properly, a penalty may also be established. The BGB law defines that penalties must only be paid if there is an intention or negligence. But the parties may relinquish that one and define stronger penalties. This, however, should not be part of the general terms of the business. A point to note is that private persons may let a judge adapt the penalty to their current financial situation $(\$ 343$ BGB), but this is not the case for firms. Nevertheless, a penalty clause becomes void if the penalty is disproportionately high. In cases like this, for example, when the penalty per day is defined as a percentage of the project's price without an upper limit, court decisions have already been made. To protect the contractor against being denied the right of getting paid, it is possible to add clauses which guarantee new negotiations for the price if external points of references, like the wages of civil servants, vary more than a specific amount. It is also possible to define a price depending on the prices of similar efforts or the contractor costs. Whether the Deutsche Bundesbank must allow such clauses, should be carefully checked (see $\S 3$ Währungsgesetz — WährG).

Finally, it should be noted that the parties may agree upon the retention money which can be replaced with a declaration of suretyship. If the retention money is part of the general terms of the business, it must be customary in the industry ( $\$ 3$ AGBG) and it must not be too high ( 9 AGBG).

\subsection{Price definitions}

When talking about price definition, we have a rather general procedure of determining a price in mind, i.e. we ought to take into account taxonomy of pricing. Discussing different price definitions is important, because the price definition used in a contract is a means of allocating risks (HÖFFKEN; SCHWEITZER, 1991; EGER, 1995 for more details on risk premiums and risk allocation, respectively).

\subsubsection{Contracts with fixed prices}

\subsubsection{Fixed-price contracts}

A fixed-price contract, sometimes called hard-money contract, is characterized by a pricing mechanism in which no provisions are made for changing the price stated in the contract. Pond (1996) reports that $88 \%$ of all heavy construction projects fall into that category. Depending on the object for which a fixed price is stated, one can discriminate:

a) lump sum contracts;

b) unit price contracts; and

c) price list contracts.

A lump sum contract defines a fixed-price for the project as a whole. Such a contract may be formulated in several variants to refine that idea. Two extremes should be highlighted. First, one can state in the contract what the result of the project should be. In such a situation, the fixed price covers any contractor's effort necessary to achieve that result. This bears the risk for the contractor since the real, necessary effort differs from the planned effort (HARTMAN; SNELGROVE, 1996). Second, a comprehensive list of planned activities with a detailed description of what is to be done becomes part of the contract. Anything that is not included in that list will not be covered by the fixed price. Usually, a fixed-price contract is a combination of both extremes in which important tasks are enumerated and the result of these tasks is defined.

In a unit price contract, the parties define a fixed-price for a single quantity of each one of the tasks that are planned to be done. These contracts are sometimes called 
bill-of-quantities contracts or remeasurement contracts. This type of contract removes the risk of inaccurate estimation of uncertain quantities for the contractor. The total to be paid is not clear in advance, but it depends on the real effort demanded. It is worth noting that a phenomenon known as unbalanced bidding has been observed (STARK, 1974). In situations where the client's estimates of the required quantities differ from the contractor's estimates and the contractor believes in his own estimates, the contractor may be tempted to raise the unit price for the tasks the client's estimate of the required quantities is lower, and he/she also may be tempted to lower the unit price for the tasks where the client's estimate is higher. If the contractor's assessment is correct, he/she can increase his profit. Furthermore, the contractor may opt to raise the unit price for tasks that have to be done first and lower the price for tasks that are scheduled to take place later. Depending on the terms of payment, this strategy may help the contractor manipulate the project cash flow.

A price list contract is in fact a unit price contract. The difference is that planned tasks are not enumerated in the contract, but instead, the contract wording refers to a comprehensive standard price list which includes all tasks (with unit prices) that may occur. Supplements and discounts enable individual modifications. It is important to mention that the use of a price list does not contradict the assumption that the project is unique. The project as a whole may be unique although the tasks to be done (or most of them) have been performed under the circumstances mentioned earlier.

\subsubsection{Price escalation contracts}

To shift some of the risks to the client the contractor will usually charge a risk premium. To reduce this effect, one may use contracts with fixed-prices, in essence, but which contain clauses that allow price modifications.

One possibility to do so is to refer to some external points of reference like, for instance, a price index for any good which can be considered as being relevant and for which such an index had been published somewhere. It must be stated in the contract what changes of that specific point of reference lead to the price adjustment. It must also be stated how the new prices are calculated.

Another possibility, known as prospective redetermination, is to split the project into smaller parts which are performed one after the other. A fixed-price is stated for the first part only. Once it is completed, a fixed-price is negotiated for the second part and so on. This, however, bears the risk that negotiations will not come to an end, and thus the project fails to be completed. This possibility is, therefore, not appealing to the client.

A combination of both is conceivable. In such situations, certain changes of an external point of reference lead to new price negotiations.
Finally, one could think of contracts with a guaranteed maximum price in which the ultimate price is negotiated after the project completion. This is known as retroactive redetermination.

\subsubsection{Contracts without fixed prices}

Unlike fixed-price contracts, we will now discuss contracts in which the price is based on incurred costs rather than on the work content. Thus, such types of contract are riskier to the client than to the contractor. Examples of the use of those contracts are projects in which the work content is hard to estimate and it is more important for the client that the project is completed fast rather than cheap, or in which the contractor is in a stronger position than the client. From the client's perspective, it is impossible to compare potential contractors regarding price, so contracts without fixed prices are not used in bidding situations when the price is an important criterion for selecting a bid. This explains why contracts without fixed prices are often called negotiated contracts while fixed-price contracts are sometimes referred to as bidding contracts.

When using contracts without a fixed price, it must be stated in the contract which costs are relevant and how the contractor should prove them. In some cases it may be that the right to audit the contractor's accounts is granted to the client (KURSATZ, 1995). For the construction industry, Carty (1995) reports that usually some certain well-defined direct costs are used for defining the price and that main office costs, costs of financing etc., are included in the agreement upon a fee.

\subsubsection{Cost reimbursement contracts}

Cost Reimbursement Contracts mean that the client agrees to reimburse the contractor in full. As a consequence, there is no immediate incentive for the contractor to keep the costs and, therefore, to keep the price low. The only incentive is to avoid a loss of goodwill in the case of having the client and the contractor working together again in the future and when there is a competition among potential contractors. Depending on how the fee is defined, one can discriminate the following types of cost reimbursement contracts:

a) cost-reimbursement contracts without a fee;

b) cost-plus-fixed-fee contracts;

c) cost-plus-percentage contracts; and

d) time-and-material contracts.

By definition, cost-reimbursement contracts without a fee are seldom accepted by commercially minded contractors. Situations where the contractor acquires know-how or improves his image may be examples where such contracts may become real.

In widespread use are contracts in which a fixed fee is stated in the contract. Some applications are reported 
by Pond(1996) who discusses tunnel construction and by Möffert (1995) who reports on R\&D.

Contracts in which the fee is determined as a percentage of the costs may let the contractor try to rise the costs intentionally in order to rise the profit. Due to this absurd situation, these contracts are usually not applied (GILBREATH, 1983; HENDRICKSON; AU, 1989). However, a certain variant of the cost-plus-percentage type of contract is commonly used, which is known as time-and-material contract. The nature of this contract is that the client reimburses the contractor for the material costs and, in addition, pays a fixed-price for every unit time that has been spent. This fixed price usually includes direct costs per unit time plus a certain percentage as a fee.

\subsubsection{Incentive contracts}

One of the main disadvantages of cost reimbursement contracts is that the client has almost no incentive to keep costs low. Adding such incentives leads to cost-plus-incentive contracts.

The basic idea of this type of contract is to work with an estimation of the costs the parties agree upon; $\mathrm{C}_{\mathrm{T}}>0$ denotes these target costs. If the real costs $\mathrm{C}>0$ are equal to the estimated costs $\mathrm{C}_{\mathrm{T}}$, the client reimburses the contractor for the costs $\mathrm{C}$ plus a fixed (target) fee, $\mathrm{F}>0$. If, however, the real costs fall above (below) the estimated costs then the price is decreased (increased) by subtracting (adding) a fraction $\lambda>0$ (which is stated in the contract) from the deviation $\mathrm{C}-\mathrm{C}_{\mathrm{T}}$. Incentive contracts are also known as incentive/disincentive contracts because the price is affected when estimated costs are exceeded as well as when real costs fall below target costs. Formally, the price is:

$$
\mathrm{C}+\mathrm{F}-\lambda\left(\mathrm{C}-\mathrm{C}_{\mathrm{T}}\right)
$$

And any positive value for $\lambda$ gives an incentive for the contractor to keep costs low. It is worth mentioning that due to the nature of Equation 1, the contractor may try to inflate the target costs.

It is easy to verify that $\lambda=0$ defines a cost-plusfixed-fee contract, which shifts the cost risks to the client and that $\lambda=1$ defines a lump sum contract, which shifts the cost risks to the contractor. So, specifying $\lambda$ in the contract allows simple wording for allocating the cost risks. It should be noted that costs will be reimbursed in full as long as $\lambda=0$ or, if $\lambda>0$ :

$$
\mathrm{C} \leq \mathrm{C}_{\mathrm{T}}+\frac{1}{\lambda} \mathrm{F}
$$

i.e. real costs fall below an upper limit. Furthermore, it is important to emphasize that if the parties agree to specify a value $\lambda>1$ which they are free to do, the price turns out to be negative if real costs exceed the upper limit.

$$
\frac{\lambda}{\lambda-1} \mathrm{C}_{\mathrm{T}}+\frac{1}{\lambda-1} \mathrm{~F}
$$

This situation is unreasonable and the contractor should insist on a minimum price to be stated in the contract if $\lambda>1$.

Variants of the cost-plus-incentive contract are conceivable. There are, for instance, fixed-price incentive contracts, also known as guaranteed maximum contracts, in which the parties stipulate a maximum price, the so-called ceiling price. If the price according to Equation 1 exceeds the maximum price, only the ceiling price has to be paid. Otherwise, the price is calculated using Equation 1.

Other variants of incentive contracts can be derived by graded multipliers $\lambda$ which depend on the amount of deviation between real costs and target costs and/or whether real costs exceed target costs or they fall below. It is also easy to give incentives for early or timely project completion. One simply uses graded multipliers $\lambda$ when the project is completed on time if compared to late completion, smaller values are used for cost overruns. If the real costs fall below the target costs, then the value of $\lambda$ should be greater for the cases when the project is completed in time than for the cases when the project is past due. In addition to cost-based and schedule-based incentives, one can also think of performance-based incentives which work similarly and take quality aspects into account.

In summary, structuring contracts with incentives as discussed above is closely related to penalties and bonuses. We refer to Herbsman (1995) who discusses the so-called $\mathrm{A}+\mathrm{B}$ bidding method as an application for cost-based and schedule-based incentives in highway construction. The role of schedule-based incentives in highway construction is also emphasized by Jaraiedi et al. (1995). Hiller and Tollison (1978) compare cost reimbursement contracts with incentive contracts and report that in the 1960s roughly a $10 \%$ reduction in the U.S. defense procurement costs was claimed to be achieved simply by switching from cost reimbursement contracts to incentive contracts.

\subsection{Terms of payment}

Besides paying the project price after inspection, the parties often wish to have payments in advance. This is trivial for the contractor, but the client may also be willing to pay at least a part of the price in advance since it reduces the financial burden of the contractor and thus reduces the risk of an unfulfilled project due to insolvency. Therefore, the client can expect the contractor to ask for a lower risk premium. This is especially true when projects last long. 
Anyhow, whenever the parties agree upon advanced payments, they should clearly define the terms of payment. Generally speaking, this includes a definition of when payments are in order and what amount of money should be paid. There are three possibilities for triggering payments:

a) payments based on time: the contractor receives payments at certain dates stated in the contract;

b) payments based on costs: the contractor receives payments whenever costs have accumulated up to certain amounts; and

c) payments based on key events (milestones): the contractor receives payments whenever certain important parts of the project have been completed.

There are also three alternatives for determining the amount of money to be paid:

a) paying fixed amounts: the amount of money to be paid is already stated in the contract;

b) payments based on costs: the amount of money to be paid is calculated on the basis of accumulated costs; and

c) progress payments: the amount of money to be paid is determined by the work content that has been completed.

Combining a way of triggering payments with a way of calculating the amount of money to be paid leads to several variants. Some sensible combinations should briefly be described.

Agreeing upon paying fixed amounts may be sensible in fixed price contracts. It is meaningless to combine it with payments based on costs, but it may be successfully combined with payments based on time or payments based on key events. If time is used as a triggering mechanism, the contractor has almost no incentive to proceed fast. Thus, such a payment term may be of no interest to the client.

Payments based on costs are straightforward for contracts without fixed prices. It may be combined with any alternative for triggering the payments. From the client's perspective, the shortcomings are that the contractor may intentionally shift costs, e.g. for material, earlier than it is actually necessary.

A strong incentive for the contractor to proceed fast is given when progress payments are used. This is true no matter what mechanism is used to trigger the payments. To avoid conflicts, it is crucial to define in the contract, precisely, how progress is measured (MARSH, 1995). Three possibilities have been extensively discussed in the literature. First, one could employ field measurement to count the number of units of the work content that have been completed (GILBREATH, 1983). Because of this, it is quite natural to use it for unit price contracts. Second, one could define a schedule of values (CLOUGH, 1975) which is often used in lump sum contracts. The basic idea is to assign fractions of the lump sum to distinct types of the overall work content. Whenever payments are in order, the contractor reports which percentage of a work type is completed. The contractor then receives that very percentage of the associated fraction of the lump sum. The obvious problem is over measurement, i.e. the contractor may tend to report higher percentages in early stages. Third, the terms of payment may totally rely on milestones (CLOUGH; SEARS, 1979). For example, Heyes and Liston-Heyes (1994) report that U.S. military procurement agencies have recently started to use progress payments. This is interesting; Hiller and Tollison (1978) have reported on the introduction of incentive contracts earlier.

\section{Bidding}

Let's consider the case where the client selects a contractor by means of a bidding procedure for the contract. Such mechanism is most appropriate for fixedprice contracts, especially for lump sum contracts.

At least two problems arise in this context. First, there is the problem for the client to design a bidding mechanism that serves his/her purposes best. This means, for example, a bidding mechanism which yields the highest price. We recommend Bulow and Roberts (1989) and Myerson (1981) for a detailed treatment of this topic. Second, there is the problem for a potential contractor to calculate a bid price that is low enough to win the contract and high enough to make a profit. Griesmer and Shubik (1963a, 1963b, 1963c), Griesmer et al. (1967), Milgrom (1989), and Milgrom and Weber (1982) provide an introduction into the field of bidding processes. Extensive surveys of the literature are given by Engelbrecht-Wiggans (1980), McAfee and McMillan (1987), Stark (1971) and Stark and Rothkopf (1979).

Within the scope of this work, it suffices to say that bidding procedures are classified according to whether or not bids are submitted open (and bid prices are altered progressively). Some authors refer to bidding procedures with open bids as auctions while others refer to bidding procedures as auctions in general. In what follows, let's confine our attention to the problem of determining a bid price where sealed bids are to be submitted and review a fundamental bidding procedure. Afterwards, we will discuss issues related to submitting bids for more than a single project.

\subsection{Friedman's bidding method}

One of the most seminal papers for competitive bidding situations is the one written by Friedman (1956). It can be applied to the following situation. Each competitive bidder submits one sealed bid where the number of bidders may be large or even unknown. The contract is 
then awarded to the lowest price bid. The problem for each of the potential contractors is to determine a lump sum for the contract in the presence of uncertain costs. It is assumed that bidders are indifferent to risks and try to maximize the expected profit. As King and Mercer (1987) have pointed out, there are five assumptions underlying this approach:

a) there is a single objective function;

b) there is an ample supply of information on competitors' bids;

c) competitors will continue to bid as they did in the past;

d) competitors bid randomly with constant parameters; and

e) competitors' bids for each contract are statistically independent.

\subsubsection{Expected profit}

We must note that the cost for fulfilling a contract is a random variable. In order to submit a bid, Friedman (1956) suggests the use of information from previous bidding situations to derive a probability distribution of the cost. Let $\mathrm{C}_{\mathrm{E}}$ denote the estimate cost. From a previous situation one can compute the ratio $C_{R}$ of the true cost $C$ and the estimated $\operatorname{cost} \mathrm{C}_{\mathrm{E}}$, i.e.

$$
\mathrm{C}_{\mathrm{R}}=\frac{\mathrm{C}}{\mathrm{C}_{\mathrm{E}}}
$$

By collecting and studying past data, one can calculate the probability density function $\mathrm{f}\left(\mathrm{C}_{\mathrm{R}}\right)$.

Now, let $\mathrm{B}$ denote the bid price for a (new) contract. The profit would be:

$$
\mathrm{B}-\mathrm{C}=\mathrm{B}-\frac{\mathrm{C}}{\mathrm{C}_{\mathrm{E}}} \mathrm{C}_{\mathrm{E}}=\mathrm{B}-\mathrm{C}_{\mathrm{R}} \mathrm{C}_{\mathrm{E}}
$$

with $\mathrm{C}$ being unknown in advance. If $\mathrm{w}\left(\mathrm{B}, \mathrm{C}_{\mathrm{E}}\right)$ is the probability to win the contract:

$$
\pi\left(B, C_{E}\right)=\int_{0}^{\infty} w\left(B, C_{E}\right)\left(B-C_{R} C_{E}\right) f\left(C_{R}\right) d C_{R}
$$

is the expected profit on the basis of past cost data.

The bidder's problem is to determine a bid price $\mathrm{B}$, so Equation 6 is maximized. Friedman (1956) argues that $\mathrm{w}$ $\left(B, C_{E}\right)$ is independent of $C_{R}$. Since:

$$
\int_{0}^{\infty} \mathrm{f}\left(\mathrm{C}_{\mathrm{R}}\right) \mathrm{dC_{ \textrm {R } }}=1
$$

the expected profit (6) then equals

$$
\pi\left(B, C_{E}\right)=w\left(B, C_{E}\right) \underbrace{\left(B-C_{E} \int_{0}^{\infty} C_{R} f\left(C_{R}\right) d C_{R}\right)}_{\bar{\pi}\left(B, C_{E}\right)}
$$

Determining the bid price that maximizes the expected profit is a more or less simple task once the expected cost curve is known.

The difficulty with this procedure lies in determining w $\left(B, C_{E}\right)$, the probability of winning the contract as a function of the bid price and the estimated cost.

\subsubsection{Winning probability}

Friedman (1956) proposes the use of previous bidding data again to determine the probability of winning a contract. He assumes that for previous bidding situations the bid prices are available. Two bidding situations for a (new) contract are then discriminated: i) situations where the identities of the competing bidders are known; and ii) situations where the identity of the competing bidders is not known.

If a bidder knows his/her competitors, he/she may collect information on the individual bidding patterns. For each competitor, the ratio of the competitor's bid price and the cost estimate, the so-called markup, is analyzed. Because the competitor's cost estimate is usually unknown, the true markup cannot be observed. In spite of that, one may estimate the true markup by studying the ratio of the competitor's bid price and one's own cost estimate. If there are enough previous observations, one can derive a distribution of this markup for each competitor. The probability to win a contract by submitting a price $B$ when the estimated cost is $C_{E}$ can be assumed to be the product of probabilities of defeating each of the competitors.

If it is not exactly known which competitors will submit a bid, or if sufficient data on a competitor's historic behavior is not available, Friedman (1956) suggests the use of an average bidder instead. The basic idea of this concept is to combine all previous estimated markups of an opposing bid to obtain a single distribution function $\mathrm{h}(\mathrm{m})$ for a markup $\mathrm{m}$. The probability to defeat one average bidder is then given to be:

$$
\int_{\frac{B}{C_{E}}}^{\infty} h(m) d m
$$

and, accordingly, the probability to defeat exactly $b$ bidders is:

$$
\left(\int_{\frac{B}{C_{E}}}^{\infty} h(m) d m\right)^{b}
$$

if $g(b)$ is the probability that $b$ competitors will submit a bid:

$$
w\left(B, C_{E}\right)=\sum_{b=0}^{\infty} g(b)\left(\int_{\frac{B}{C_{E}}}^{\infty} h(m) d m\right)^{b}
$$

is the winning probability. 


\subsubsection{Related work}

The Friedman model has been the focus of numerous publications which input and put forward the proposed ideas. Hanssmann and Rivett (1959) suggest that not all of the observations previously mentioned should be used, but only those belonging to winning bids and which simplifies data collection. Grinyer and Whittaker (1974) investigate the use in four building industry and incorporate market trend cases. McCaffer and Pettitt (1976) study the distribution of bids for building works and for roadworks and find that they can be treated as normal distribution samples. Naert and Weverbergh (1978) research issues related to the uncertainty about cost estimates. Sugrue (1982) have computed the so-called bidding tables which provide bid prices in order to ease the use of bidding procedures in practical situations. King and Mercer (1985) discuss problems about determining bidding strategies and in King and Mercer (1988) they review some controversy about Friedman's approach. In King and Mercer (1990), they perform a computational study to examine different distributions of the cost estimate, different versions of the expected profit, and different formulae for the probability of winning. Ward and Chapman (1988) consider using information requirements for developing a bid price to maximize the expected profit. Engwall (1975) questions the correlation between the price and the probability to win and discusses the importance of permanent relations between the client and the contractor. Attwell and Smith (1991) investigate the case where bids for a sequence of contracts should be submitted using Gates' procedure (GATES, 1967), a variant of Friedman's approach, as a basis.

A phenomenon known as the winner's curse occurs when a successful bidder finds that the real costs exceed the price he had submitted. This phenomenon is not specific to Friedman's approach (BAZERMAN; SAMUELSON 1983; HANSEN; LOTT, 1991; KAGEL; LEVIN, 1986; KAGEL; LEVIN, 1991; LEVIN; SMITH, 1991; LIND; PLOTT, 1991; THALER, 1988; THIEL, 1988). Winkler and Brooks (1980) study situations where the errors of cost estimation are interdependent, and they investigate the effect on the winner's curse. Römhild (1997) shows how to modify Friedman's bidding method to predict the winner's curse.

\subsection{Resource-constrained bidding}

Now let's consider situations in which the contractor wishes to submit bids for more than a single project. In cases where the projects compete for common resources, such as when the contractor is not in the position to execute all projects under consideration, the contractor must make a choice. We assume that a set of $\mathrm{P}$ projects are taken into account, and that all of them are identified before a bid is submitted. Furthermore, we assume that a single resource is to be taken into account which provides $\mathrm{R}$ resource units. The assumption of a single resource is made for the sake of simplicity only. It is straightforward to handle the multiple resource case analogously. The amount of resource units consumed by a project $\mathrm{p} \in \mathrm{P}$ is known to be $r_{p} \in I R$. Finally, we assume that once a contract is awarded, the contractor cannot reject the project which means that the bidding strategy should focus on avoiding exceeding the available resource units.

How to adapt Friedman's method for this situation has been demonstrated by reviewing the basic principles discussed in the literature. Two cases are discriminated. First, there may be cases where bids can be submitted sequentially and a contract is awarded before the next bid is submitted. Second, there may be cases where multiple bids must be submitted simultaneously. Combinations of these two cases are possible, but are not considered here. The adaption of the Friedman approach to these two cases has previously been studied by Knode and Swanson (1978), who apply dynamic programming, and by Römhild (1997). Stark and Mayer (1971) also use Friedman's method as a basis to suggest a bunch of models and methods. Hausch (1986)presents the client's perspective and discusses the question of whether and when the client should prefer sequential or simultaneous bidding procedures. Kortanek et al. (1973) present several bidding models for cases of sequential bidding, and Attanasi (1974) provides an interpretation that the result of sequential bidding models include likely actions of competing bidders. Goodman and Baurmeister (1976) propose dynamic programming to solve sequential bidding problems. Pitchik and Schotter (1988) present an experimental study of bidding behavior in sequential auctions.

\subsubsection{Sequential bidding}

Let the projects under consideration be denoted by $\mathrm{p}=1, \ldots,|\mathrm{P}|$ where bids are to be submitted in the order of ascending project numbers. Since we use the same assumptions as in the Friedman approach, the objective is to maximize the expected profit. Let $\Pi_{p}\left(R^{\prime}\right)$ denote the expected profit when bidding for projects $\mathrm{p}, \ldots,|\mathrm{P}|$, i.e. the contracts for projects $1, \ldots, \mathrm{p}-1$ have already been awarded, and R' resource units are still available. Formally, $\Pi_{p}\left(R^{\prime}\right)$ can be computed by solving a dynamic program that makes use of Equation 8 for calculating the expected profit $\pi_{p}\left(B_{p}\right)$ of a single project $p$ when the bid price is $\mathrm{B}_{\mathrm{p}}, \mathrm{C}_{\mathrm{Ep}}$ is the estimated cost for project $\mathrm{p}$, and $w p\left(B_{p}, C_{E p}\right)$ is the winning probability.

If $\mathrm{R}^{\prime}-\mathrm{r}_{\mathrm{p}} \geq 0$, i.e. the available resource units are sufficient to perform project $\mathrm{p}$; the expected profit is

$\Pi_{\mathrm{p}}\left(\mathrm{R}^{\prime}\right)=$ 
$\max _{\mathrm{B}_{\mathrm{p}}}\left\{\begin{array}{c}\pi_{\mathrm{p}}\left(\mathrm{B}_{\mathrm{p}}, \mathrm{C}_{\mathrm{Ep}}\right)+\mathrm{w}_{\mathrm{p}}\left(\mathrm{B}_{\mathrm{p}}, \mathrm{C}_{\mathrm{Ep}}\right) \prod_{\mathrm{p}+1}\left(\mathrm{R}^{\prime}-\mathrm{r}_{\mathrm{p}}\right) \\ +\left(1-\mathrm{w}_{\mathrm{p}}\left(\mathrm{B}_{\mathrm{p}}, \mathrm{C}_{\mathrm{Ep}}\right)\right) \Pi_{\mathrm{p}+1}\left(\mathrm{R}^{\prime}\right)\end{array}\right\}$

otherwise, project $\mathrm{p}$ cannot be accepted and we simply have

$$
\prod_{\mathrm{p}}\left(\mathrm{R}^{\prime}\right)=\prod_{\mathrm{p}+1}\left(\mathrm{R}^{\prime}\right)
$$

We define $\Pi_{|\mathrm{P}|+1}(\cdot)=0$. The sequential bidding problem can then be defined by finding bid prices $\mathrm{B}_{\mathrm{p}}$ for each of the projects so that $\Pi_{1}(R)$ is maximized.

\subsubsection{Simultaneous bidding}

Using the same notation as above if the bids for the $\mathrm{p}=1, \ldots,|\mathrm{P}|$, contracts must be submitted simultaneously. The expected profit when having $\mathrm{R}$ resource units available can be defined as

$$
\begin{aligned}
& \sum_{\mathrm{x}_{1}=0}^{1}\left(\left(\mathrm{x}_{1} \mathrm{w}_{1}\left(\mathrm{~B}_{1}, \mathrm{C}_{\mathrm{E} 1}\right)+\left(1-\mathrm{x}_{1}\right)\left(1-\mathrm{w}_{1}\left(\mathrm{~B}_{1}, \mathrm{C}_{\mathrm{E} 1}\right)\right)\right)\right. \\
& \sum_{\mathrm{x}_{2}=0}^{1}\left(\left(\mathrm{x}_{2} \mathrm{w}_{2}\left(\mathrm{~B}_{2}, \mathrm{C}_{\mathrm{E} 2}\right)+\left(1-\mathrm{x}_{2}\right)\left(1-\mathrm{w}_{2}\left(\mathrm{~B}_{2}, \mathrm{C}_{\mathrm{E} 2}\right)\right)\right)\right. \\
& \cdots \\
& \sum_{\mathrm{x}_{\mid \mathrm{P}}=0}^{1}\left(\left(\mathrm{x}_{|\mathrm{P}|} \mathrm{w}_{|\mathrm{P}|}\left(\mathrm{B}_{|\mathrm{P}|}, \mathrm{C}_{\mathrm{E}|\mathrm{P}|}\right)+\left(1-\mathrm{x}_{|\mathrm{P}|}\right)\left(1-\mathrm{w}_{|\mathrm{P}|}\left(\mathrm{B}_{|\mathrm{P}|}, \mathrm{C}_{\mathrm{E}|\mathrm{P}|}\right.\right.\right.\right. \\
& \left.\left.\left.\cdot\left(\sum_{\mathrm{p} \in \mathrm{P}} \mathrm{x}_{\mathrm{p}} \bar{\pi}_{\mathrm{p}}\left(\mathrm{B}_{\mathrm{p}}, \mathrm{C}_{\mathrm{Ep}}\right)-\mathrm{x}\left(\mathrm{R}-\sum_{\mathrm{p} \in \mathrm{P}} \mathrm{x}_{\mathrm{p}} \mathrm{r}_{\mathrm{p}}\right)\right)\right) \ldots\right)\right) .
\end{aligned}
$$

\section{Referências bibliográficas}

ATTANASI, E. Some Interpretations of Sequential Bid Pricing Strategies. Management Science, v. 20, p. 1424-1427, 1974,

ATTWELL, D. N.; SMITH, J. Q. A Bayesian Forecasting Model for Sequential Bidding. Journal of Forecasting, v. 10, p. 565-577, 1991

BAZERMAN, M.; SAMUELSON, W. The Winner's Curse: An Empirical Investigation. In: TIETZ, R. (Ed.). Aspiration Levels in Bargaining and Economic Decision Making, New York, Springer, p. 186-200, 1983.

BULOW, J.; ROBERTS, J. The Simple Economics of Optimal Auctions. Journal of Political Economy, v. 97, p. 1060-1090, 1989.

CARTY, G. J. Construction. Journal of Construction Engineering and Management, v. 121, p. 319-328, 1995

CLOUGH, R. H. Construction Contracting. 3. ed. New York: Wiley, 1975

ClOUGH, R. H.; SEARS, G. A. Construction Project Management. New York: Wiley, 1979

EGER, T. Eine ökonomische Analyse von Langzeitverträgen. Marburg: Metropolis, 1995.
The term $\pi_{\mathrm{p}}\left(\mathrm{B}_{\mathrm{p}}, \mathrm{C}_{\mathrm{Ep}}\right)$ is defined in accordance to (8) and the expression $\chi\left(\mathrm{R}^{\prime}\right)$ is a penalty term which is defined as

$$
x\left(R^{\prime}\right)=\left\{\begin{array}{l}
\infty, \text { if } R^{\prime}<0 \\
0, \text { otherwise }
\end{array}\right.
$$

Ensuring that a solution in which the resource constraint is violated, is not an optimal solution.

The simultaneous bidding problem can now be defined as finding bid prices $B_{p}$ in such a way that the expected profit is maximized.

\section{Summary and conclusion}

In this paper we have reviewed aspects related to contracting and bidding in the context of project management. We have introduced the reader to German law to create a feeling of what is customary and allowed in Germany. We have also discussed several ways of defining a project price. To show how payments can be triggered, we have compiled possible terms of payments as well. For the situations where clients select a contractor, we have discussed bidding procedures. The issues discussed do have a strong impact on further project management tasks. Scheduling, for instance, affects the timing and, for a given point of time, the amount of payment, depending on the specific setting. Future studies on project scheduling should, therefore, not only stress the objective of makespan minimization but also focus more on financial objectives (KIMMS, 2001).
ENGELBRECHT-WIGGANS, R. Auctions and Bidding Models: A Survey. Management Science, v. 26, p. 119-142, 1980.

ENGWALL, L. To Bid or Not to Bid, Omega. The International Journal of Management Science, v. 3, p. 395-401, 1975.

FRIEDMAN, L. A Competitive Bidding Strategy. Operations Research, v. 4, p. 104-112, 1956.

GATES, M. Bidding Strategies and Probabilities, Journal of the Construction Division. Proceedings of the American Society of Civil Engineers, v. 93, p. 75-107, 1967

GILBREATH, R. D. Managing Construction Constracts Operational Controls for Commercial Risks, New York: Wiley, 1983

GOODMAN, D.; BAURMEISTER, H. A Computational Algorithm for Multi-Contract Bidding under Constraints. Management Science, v. 22, p. 788-798, 1976.

GRIESMER, J. H.; SHUBIK, M. Toward a Study of Bidding Processes: Some Constant-Sum Games. Naval Research Logistics Quarterly, v. 10, p. 11-21, 1963. 
GRIESMER, J. H.; SHUBIK, M. Toward a Study of Bidding Processes, Part II: Games With Capacity Limitations. Naval Research Logistics Quarterly, v. 10, p. 151-173, 1963.

Toward a Study of Bidding Processes, Part III: Some Special Models. Naval Research Logistics Quarterly, v. 10, p. 199-217, 1963.

GRIESMER, J. H.; LEVITAN, R. E.; SHUBIK, M. Toward a Study of Bidding Processes, Part IV: Games With Unknown Costs. Naval Research Logistics Quarterly, v. 14, p. 415-433, 1967.

GRINYER, P. H.; WHITTAKER, J. D. Managerial Judgement in a Competitive Bidding Model. Operational Research Quarterly, v. 24, p. 181-191, 1974.

HANSEN, R. G.; LOTT, J. R. The Winner's Curse and Public Information in Common Value Auctions: Comment. American Economic Review, v. 81, p. 347-361, 1991

HANSSMANN, F.; RIVETT, B. H. P. Competitive Bidding. Operational Research Quarterly, v. 10, p. 49-55, 1959.

HARTMAN, F.; SNELGROVE, P. Risk Allocation in Lump-Sum Contracts - Concept of Latent Dispute. Journal of Construction Engineering and Management, v. 122, p. 291-296, 1996.

HAUSCH, D. B. Multi-Object Auctions: Sequential vs. Simultaneous Sales. Management Science, v. 32, p. $1599-1610,1986$.

HENDRICKSON, C.; AU, T. Project Management for Construction - Fundamental Concepts for Owners, Engineers, Architects, and Builders. Englewood Cliffs: Prentice Hall, 1989.

HERBSMAN, Z. J. A+B Bidding Method - Hidden Success Story for Highway Construction. Journal of Construction Engineering and Management, v. 121, p. 430-437, 1995.

HEYES, A. G.; LISTON-HEYES, C. Progress Payments and Cost Overruns in Defense Contracts. Defense and Peace Economics, v. 5, p. 289-299, 1994.

HILLER, R. J.; TOLLISON, R. D. Incentive Versus Cost-Plus Contracts in Defense Procurement. Journal of Industrial Economics, v. 26, p. 239-248, 1978.

HÖFFKEN, E.; SCHWEITZER, M. (Eds.) Beiträge zur Betriebswirtschaft des Anlagenbaus, Zeitschrift für betriebswirtschaftliche Forschung, Sonderheft 28, 1991

HORGan, M. O' C.; ROUlSton, F. R. Project Control of Engineering Contracts. London: Spon, 1989

JARAIEDI, M.; PLUMMER, R.W.; ABER, M. S. Incentive/ Disincentive Guidelines for Highway Construction Contracts. Journal of Construction Engineering and Management, v. 121, p. 112-120, 1995.

KAGEL, J. H.; LEVIN, D. The Winner's Curse and Public Information in Common Value Auctions. American Economic Review, v. 76, p. 894-920, 1986.

KAGEL, J. H.; LEVIN, D. The Winner's Curse and Public Information in Common Value Auctions: Reply. American Economic Review, v. 81, p. 362-369, 1991.

KIMMS, A. Mathematical Programming and Financial Objectives for Scheduling Projects. Boston, Kluwer, 2001

KING, M.; MERCER, A. Problems in Determining Bidding Strategies, Journal of the Operational Research Society, v. 36, p. 915-923, 1985

KING, M.; MERCER, A. Note on a Conflict of Assumptions in Bidding Models. European Journal of Operational Research, v. 32, p. 462-466, 1987.

Recurrent Competitive Bidding. European Journal of Operational Research, v. 33, p. 2-16, 1988
The Optimum Markup when Bidding with Uncertain Costs. European Journal of Operational Research, v. 47, p. 348-363, 1990.

KNODE, C. S.; SWANSON, L. A. A Stochastic Model for Bidding, Journal of the Operational Research Society, v. 29, p. 951-957, 1978.

KORTANEK, K. O.; SODEN, J. V.; SODARO, D. Profit Analyses and Sequential Bid Pricing Models. Management Science, v. 20, p. 396-417, 1973.

KURSATZ, D. M. Transaktionskosten bei Bauverträgen: Probleme der Vertragsgestaltung und -durchsetzung. Lang: Frankfurt a.M., 1995

LEVIN, D.; SMITH, J. L. Some Evidence on the Winner's Curse: Comment. American Economic Review, v. 81, p. 370-375, 1991.

LIND, B.; PLOTT, C. R. The Winner's Curse: Experiments with Buyers and with Sellers. American Economic Review, v. 81, p. 335-346, 1991.

LOCHER, U. Die Rechnung im Werkvertragsrecht, Düsseldorf: Werner, 1990

MARSH, P. D. V. Contracting for Engineering and Construction Projects. Aldershot/Hampshire, Gower, 4. ed. 1995

MCAFEE, R. P.; MCMILLAN, J. Auctions and Bidding. Journal of Economic Literature, v. 25, p. 699-738, 1987.

MCCAFFER, R.; PETTITT, A. N. Distribution of Bids for Buildings and Roads Contracts. Operational Research Quarterly, v. 27, p. 835-843, 1976.

MILGROM, P. Auctions and Bidding: A Primer. Journal of Economic Perspectives, v. 3, p. 3-22, 1989.

MILGROM, P.; WEBER, R. J. A Theory of Auctions and Competitive Bidding. Econometrica, v. 50, p. 1089-1122, 1982.

MÖOFFERT, F. J. Der Forschungsvertrag. München: Beck, 1995.

MYERSON, R. B. Optimal Auction Design. Mathematics of Operations Research, v. 6, p. 58-73, 1981.

NAERT, P. A.; WEVERBERGH, M. Cost Uncertainty in Competitive Bidding Models. Journal of the Operational Research Society, v. 29, p. 361-372, 1978.

NEO, R. B. International Construction Contracting - A Critical Investigation into Certain Aspects of Financing, Capital Planning and Cash Flow Effects. Epping: Gower, 1976.

PITCHIK, C.; SCHOTTER, A. Perfect Equilibria in BudgetConstrained Sequential Auctions: An Experimental Study. RAND Journal of Economics, v. 19, p. 363-388, 1988.

POND, R. A. Underground Contracts for the $21^{\text {st }}$ Century. Civil Engineering, v. 66, p. 54-57, 1996.

RÖMHILD, W. Preisstrategien bei Ausschreibungen. Berlin: Duncker\&Humblot, 1997.

SHTUB, A.; BARD, J. F.; GLOBERSON, S. Project Management - Engineering, Technology, and Implementation. Englewood Cliffs: Prentice-Hall, 1994.

STARK, R. M. Competitive Bidding: A Comprehensive Bibliography. Operations Research, v. 19, p. 484-490, 1971.

. Unbalanced Highway Contract Tendering. Operational Research Quarterly, v. 25, p. 373-388, 1974.

STARK, R. M.; MAYER, R. H. Some Multi-Contract DecisionTheoretic Competitive Bidding Models. Operations Research, v. 19, p. 469-483, 1971.

STARK, R. M.; ROTHKOPF, M. H. Competitive Bidding: A Comprehensive Bibliography. Operations Research, v. 27, p. 364-390, 1979. 
SUGRUE, P. Optimum Bid Estimation on Fixed Cost Contracts. Journal of the Operational Research Society, v. 33, p. 949-956, 1982.

THALER, R. H. Anomalies - The Winner's Curse. Journal of Economic Perspectives, v. 2, p. 191-202, 1988.

THIEL, S. E. Some Evidence on the Winner's Curse. American Economic Review, v. 78, p. 884-895, 1988.
TWORT, A. C.; REES, J. G. Civil Engineering: Supervision and Management. 3. ed. London: Arnold, 1995.

WARD, S. C.; CHAPMAN, C. B. Developing Competitive Bids: A Framework for Information Processing. Journal of the Operational Research Society, v. 39, p. 123-134, 1988.

WINKLER, R. L.; BROOKS, D. G. Competitive Bidding with Dependent Value Estimates. Operations Research, v. 28, p. 603-613, 1980.

\section{Sobre os autores}

\section{Alf Kimms}

Mercator School of Management, University of Duisburg-Essen, Lotharstr 65, 47048, Duisburg, Germany, e-mail: alf.kimms@uni-due.de 
